\title{
A French translation of the obsessive-compulsive drinking scale for craving in alcohol-dependent patients : A validation study in Belgium, France, and Switzerland
}

M. Ansseaua, J. Besson'b, M. Lejoyeuxc, E. Pintoa, U. Landryb, M. Cornesd, F. Deckerse, A. Potgieterf, J. Adesg

aDepartment of Psychiatry and Medical Psychology, CHU du Sart Tilman, Liège, Belgium;

bPPU B, Lausanne, Switzerland;

cService de Psychiatrie d'Urgence, Hôpital Bichat, Paris, and

${ }^{d}$ Groupe Lipha, Lyon, France,

eMerck-Belgolabo, Overijse, Belgium;

${ }^{f}$ Mas de Bellecombe, Antibes, and

${ }^{g}$ Centre Hospitalier Louis-Mourier, Colombes, France

KEYWORDS: craving, alcohol dependence, rating scale

\section{ABSTRACT}

The Obsessive-Compulsive Drinking Scale (OCDS) is an instrument developed to measure cognitive aspects of alcohol craving. The aim of this study was to validate the French translation of the OCDS according to the international methodology as published by Hunt and coworkers (see text), including forward-backward translations, patient interviews ( 9 patients), patient's perception of acceptability (15 patients), and final validation within a treatment program (50 patients). All 74 patients were native French-speaking alcohol-dependent patients from Belgium, France, and Switzerland. The derived aggregated total (TOT) score and both subscores corresponding to the obsessive (OB) and compulsive (CP) dimensions were shown to be asymptomatically normal. Good internal consistencies were found, with Cronbach alpha: TOT = $0.88 ; \mathrm{OB}=0.82 ; \mathrm{CP}=0.79$. The test-retest procedure was used to examine intrarater reliability $(\mathrm{r}=0.81)$. The construct validity was examined with linear correlation of the two main components: $\mathrm{r}(\mathrm{OB}, \mathrm{CP})=0.62 ; \mathrm{r}(\mathrm{OB}, \mathrm{TOT})=0.86 ; \mathrm{r}(\mathrm{CP}, \mathrm{TOT})=0.92$. Principal-components analysis revealed two main factors: the first factor representing the total scale score, while the obsessive and compulsive subscale scores were distributed along factor two. The translated scale seems to be psychometrically as valid as the original English scale and confirms the psychometric properties of the OCDS. 


\section{Introduction}

Craving for alcohol is an important concept in alcohol dependency. The notion of craving is ill defined, and the interpretation thereof differs among alcohol-dependent individuals as well as professional caregivers. The reliability of measuring craving with simple analogue scales, often used in pharmacotherapy trials, has been questioned. The Obsessive-Compulsive Drinking Scale (OCDS) was developed by Anton et al. $[1,2]$ to measure cognitive aspects of craving. It was also dedicated to evaluate the global severity of alcoholism and to provide some clinical definition of craving. (Meaning uncertain?)

The OCDS is a modification of the Yale-Brown Obsessive Compulsive Scale for heavy drinking (YBOCS-hd) [3], based on the similarity of many of the aspects of craving for alcohol to the thought patterns and behaviour of patients with obsessive-compulsive illness. The YBOCS-hd is an interviewer-based scale which is time-consuming and needs a trained interviewer. The OCDS is a self-report questionnaire consisting of 14 items which can be divided into one subscale with six 'obsessive' and one with eight 'compulsive' items. It is easy to administer, takes on average 15 min to complete, seems well accepted by patients and compared favourably with the YBOCShd in a sample of 60 alcohol-dependent individuals [1]. The correlation between the total scores of the YBOCS-hd and the OCDS was good $(r=0.83)$. The test-retest correlation of the OCDS was excellent $(r-r=0.96)$, and the internal consistency was good (Cronbach $\alpha=0.86)$. The shared variance between the OCDS scores and alcohol consumption was only $20 \%$, indicating that 'craving' was somewhat independent of actual drinking.

A further prospective study [2] also substantiated the validity of the OCDS as an instrument capable of measuring craving for alcohol in alcohol dependence. This study showed that as the severity of the illness increased, so did the intensity of the obsessive thoughts about alcohol and the compulsive behaviour to use alcohol. The OCDS total and subscale scores remained low in abstaining patients. Patients who drank alcohol without relapsing (relapse is defined as a consumption of five or more units of alcohol over 2 consecutive days) had higher scores than those who remained abstinent. Patients who relapsed had the highest scores. Patients with higher scores early in treatment had greater alcohol consumption in the following weeks. These findings suggest that the OCDS may be useful to identify individuals at risk of relapsing and the possible effect of anticraving therapy.

The OCDS has been successfully translated into Dutch [4] according to the methodology published by Hunt et al. [5]. This translated scale was reported to be psychometrically as valid as the original scale.

The aim of the present study was to translate the OCDS into French according to the same validated translation methodology and to examine the psychometric properties of this translation. Since differences exist between the spoken French in France, Belgium, and Switzerland and since the scale is a self-rating questionnaire, the validation study was conducted in all three of these countries. It should be considered that some concepts developed in the scale are rather complicated or intellectual and that their understanding must be verified in the daily practice. 


\section{Methods}

\section{TRANSLATION}

The OCDS was translated from English into French according to the following four steps [5].

(1) Forward-Backward Translations. Two forward and two backward translations were performed by four independent translators (one being one of the authors). The contents of all items were compared with the original English version regarding conceptual equivalence. Discrepancies were discussed and a decision was made on the most appropriate translation by the translators (translation version 1).

(2) Patient Interviews. Independent of the OCDS, 9 patients (3 from each country) were interviewed to ensure familiarity with lay terminology used by patients. During taped interviews, patients were asked open questions about alcoholism, craving, and concepts related to the OCDS. On the basis of the translation version 1 and information gathered through the patient interviews a translation version 2 was complied. A terminology more acceptable to the lay French speaking populations was included where necessary.

(3) Scale Acceptability. The acceptability of this version 2 was tested in 15 patients (5 from each country). These patients were asked to complete the OCDS questionnaire and in a second questionnaire were asked to comment on the acceptability and their understanding of the individual items. A panel of medical experts, including four of the authors, subsequently reviewed the comments made by the 15 patients and amended the items where necessary to compile the final translation (see Appendix).

(4) Translation Validity. This French OCDS was then administered to 50 patients (10 in Belgium, 20 in France, and 20 in Switzerland) to assess the psychometric properties of the scale. All 50 patients were asked to participate in a test-retest procedure to assess intrarater reliability by repeating the questionnaire after $24-48 \mathrm{~h}$.

\section{SUBJECTS}

All 50 patients who participated in the validation process met the DSM IV criteria for alcohol dependence [6, 7]. All patients were receiving alcohol weaning treatment at the time of the study and were abstinent for a maximum of 2 weeks. Patients were excluded from the study, if they had a relapse within $24 \mathrm{~h}$ before completing the questionnaire, if they had a history of substance abuse (except for nicotine) during the previous 3 months, if they had pronounced psychiatric syndromes or mental incapacity, or if there was any other reason which would prevent clear understanding of the questionnaire.

\section{STATISTICS}

Undimensional analysis of the individual items was done to calculate descriptive statistics and distribution to evaluate possible floor/ceiling effects. The aim was to examine whether particular 
items showed dissymmetrical behaviour or excessive truncation. Each OCDS item scored from 0 to 4. Similar to the English OCDS, and based on the comparison with the ten-item YBOCS-hd, the score of the scale and its two subscales was calculated as follows:

$\mathrm{OB}=\max (\mathrm{i} 1, \mathrm{i} 2)+\mathrm{i} 3+\mathrm{i} 4+\mathrm{i} 5+\mathrm{i} 6$

$\mathrm{CP}=\max (\mathrm{i} 7, \mathrm{i} 8)+\max (\mathrm{i} 9, \mathrm{i} 10)+\mathrm{i} 11+\mathrm{i} 12+\max (\mathrm{i} 13, \mathrm{i} 14)$

This means that the maximum score for each subscale was 20 and 40 for the total score. Linear Pearson correlation analysis was done on the 14 items of the scale. Cronbach $\alpha$ was used to assess internal consistency of the questionnaire. With this method the linear correlation between items must be positive. Obsessive and compulsive components were distinguished.

Intrarater reliability was assessed with Pearson linear correlation between each subscore and the total scale score. The Cronbach $\alpha$ and the Pearson correlation ' $r$ ' were used, so that results could be compared with those of Anton et al. $[1,2]$. Construct validity was examined with principal-components analysis. This was performed on all 14 items of the OCDS. The two subscales as well as the total scale were projected into the analysis.

The analysis tested for interaction between scale scores and demographic and psychiatric histories.

\section{Results}

\section{PATIENTS}

The demographic characteristics of the subjects are presented in table 1. Thirty-two males and 18 females entered the study. The majority of the patients were married, but a slightly higher proportion of male patients were single. Although male patients had a higher degree of education, more males were unemployed. No marked age difference was noted between the gender categories. Mean duration of alcoholism was slightly less in the female patients. The mean alcohol consumption before the study showed a large variability and a higher alcohol consumption in males. Slightly more males received psychotropic medication. The alcoholism duration was longer in older patients. Psychotropic drug use and psychosocial support were similar in each age category.

Some interesting variation was noted between the countries. The single status rate was slightly higher in Belgium, while most of the French and Swiss patients were married. The Swiss patients had a lower educational level, a lower frequency of psychotropic drug use, and a significantly shorter mean duration of alcoholism. The French sample had a higher mean age and more retired patients, while most of the Swiss and Belgian patients were in fulltime employment. The Belgium sample had the most psychosocial support. The daily alcohol consumption was comparable in the three countries. 
Table 1. Demographic characteristics of the subjects $(n=50)$

\begin{tabular}{ll}
\hline Males & $32(64 \%)$ \\
Females & $18(36 \%)$ \\
Marital status, \% & \\
$\quad$ Married & 48 \\
$\quad$ Single & 22 \\
$\quad$ Divorced/separated & 30 \\
Education, \% & \\
$\quad$ Primary (<12 years) & 38 \\
$\quad$ Secondary (12-18 years) & 36 \\
$\quad$ Higher ( $>18$ years) & 26 \\
Employment status, $\%$ & \\
$\quad$ Full-time working & 36 \\
$\quad$ Part-time working & 4 \\
$\quad$ Nonprofessional & 10 \\
$\quad$ Unemployed & 24 \\
$\quad$ Retired & 26 \\
Age, $\%$ & \\
$\quad<40$ years & 10 \\
$\quad 40-49$ years & 40 \\
$\quad>49$ years & 50 \\
Mean duration of alcoholism, years & $14.0 \pm 10.4$ \\
Mean alcohol intake before treatment \\
(number of drinks/day: standard = 250 ml beer, \\
100 ml wine, 25 ml spirits) \\
Psychotropic medication, \% \\
Psychosocial support, \% \\
$\quad$
\end{tabular}

Table 2. Mean values, standard deviations, and reliability scores of the OCDS total scales and subscales and intercorrelations between OCDS total scale and subscale scores of the OCDS of Anton et al. [1, 2] and the translated Dutch [4] and French scales (OCDS - Dutch and OCDS - French)

\begin{tabular}{|c|c|c|c|}
\hline & OCDS & OCDS - Dutch & OCDS - French \\
\hline TOT score, mean $\pm \mathrm{SD}$ & $22.5 \pm 7.5$ & $12.2 \pm 7.7$ & $11.3 \pm 7.6$ \\
\hline OB score, mean \pm SD & $9.5 \pm 4.8$ & $5.9 \pm 3.9$ & $5.9 \pm 4.2$ \\
\hline $\mathrm{CP}$ score, mean $\pm \mathrm{SD}$ & $13.2 \pm 3.5$ & $6.3 \pm 4.6$ & $5.5 \pm 4.1$ \\
\hline$\alpha(\mathrm{TOT})$ & 0.86 & 0.89 & 0.88 \\
\hline$\alpha(\mathrm{OB})$ & 0.85 & 0.79 & 0.82 \\
\hline$\alpha(\mathrm{CP})$ & 0.73 & 0.85 & 0.79 \\
\hline $\mathrm{r}(\mathrm{OB}, \mathrm{CP})$ & 0.62 & 0.66 & 0.68 \\
\hline $\mathrm{r}(\mathrm{CP}, \mathrm{TOT})$ & 0.86 & 0.93 & 0.91 \\
\hline $\mathrm{r}(\mathrm{OB}, \mathrm{TOT})$ & 0.92 & 0.89 & 0.92 \\
\hline
\end{tabular}

\section{PSYCHOMETRIC PROPERTIES}

Mean values and standard deviations of total and subscores, reliability coefficients, and intercorrelations of total score (TOT) and the two subscales (OB and CP) of the French OCDS, the Dutch version, and the original scale are presented in table 2. 
The undimensional analysis of the items revealed an asymmetric distribution with more low than high values. The individual items showed a moderate floor effect and no ceiling effect. The Kolmogorov-Smirnov test did not reject goodness of fit with a normal distribution for neither the total scale nor the subscales. The $\mathrm{OB}, \mathrm{CP}$, and TOTscore distributions could be considered close enough to a normal Gaussian distribution to be analyzed following general analysis of variance procedures.

The linear Pearson correlations were reasonably high and, except for some isolated values, uniformly positive. The reliability of the total scale and subscales as tested with Cronbach $\alpha$ was good and almost identical to that of Anton et al. [1,2].

Concerning the test-retest reliability, two items, No. 5 (effort that the patient makes to resist alcohol thoughts) and No. 12 (effort that the patient makes to resist alcohol consumption) showed relatively low correlation (36 and 44\%, respectively) between the assessment. Items dealing with the drive to consume alcohol (item 13) and distress caused by alcohol thoughts (item 4) showed some variation between the test and retest measurements (item $13, r=56$, and item $4, r=0.58$ ). However, the aggregated scores of obsessive and compulsive subscales and total scale remained reasonably comparable. The reliability was not influenced by sex, but single patients had a more stable score. This could probably be explained by the fact that the single patients had a lower alcohol consumption and were younger. Lower educated patients were much less stable than those with secondary education. The employment status showed a difference between full-time and part-time workers as well as retired individuals. Older patients (1 49 years) showed a lower reliability. Psychotropic drug use did not influence the reliability, but psychosocial support seemed to influence reliability negatively. The negative influence of psychosocial support could not be explained by any other variable. The country of origin did not influence reliability.

Construct validity was assessed by examining the intercorrelations between subscales (table 2). These correlations were very high and similar to those of Anton et al. [1, 2]. The Dutch study had similar correlations [4]. Construct validity was also tested by examining the factorial structure of the scale. Principal-components analysis was done to detect underlying dimensionality of the scale. The results confirmed that the OCDS is a two-dimensional scale consisting of the obsessive and compulsive components. The aggregated main score was confounded with factor one. The $\mathrm{OB}$ and $\mathrm{CP}$ partial scores were distributed along factor two.

The influences of demographic factors and psychiatric history on the scale scores were examined by calculating the cross-tabulating scores on these factors with OCDS scores and testing with one-way fixed analysis of variance. No significant results were reached, although it must be noted that the small sample size dramatically reduces the significance of the analysis of variance. The relative variability seemed to be high. Thus the demographic variables could not be shown to have any influence on the scale score.

\section{Discussion}

The findings of this study suggest that the OCDS has been successfully translated into French. The translated scale has a high psychometric resemblance to the original scale. 
The demographic characteristics of our sample seem to be similar to that of Anton et al. [1] and typical of alcoholic patients: age 40-60 years, often single or separated, with a mean daily intake of 20 drinks.

Individual items showed moderate floor effect which means that more patients recorded low values than high values. In the questionnaire, the lower scores are the first ones in the list of answers. However, the aggregated scores could be considered as asymptotically normal. The internal consistency was satisfactory for the three aggregated scales, with values very similar to those of Anton et al. [1, 2] as well as those of the Dutch study. To interpret internal consistency correctly, one has to be sure that the items were well understood. The factorial structure confirms the good construct validity. The intercorrelations between OCDS total scale and subscale were high with values very similar to those obtained by Anton et al. [1,2] as well as the Dutch study.

Intrarater reliability was, however, somewhat lower in this study $(0 \mathrm{~B}, \mathrm{r}=0.82 ; \mathrm{CP}, \mathrm{r}=0.77$; TOT, $r=0.81)$ than in that of Anton et al. [1] (0B, r = 0.94; CP, $r=0.86$; TOT, $r=0.96)$. This difference was probably due to the settings in which the patient inclusion were made, with a single site in the study of Anton et al. [1] and three sites in our study. In particular, two items, No. 5 (effort that the patient makes to resist alcohol thoughts) and No. 12 (effort that the patient makes to resist alcohol consumption), showed a relatively low correlation (36 and 44\%, respectively) between the assessments. It should be noted that it is still uncertain how stable or unstable alcohol craving is during the early phase of alcohol withdrawal and that test-retest measurements may not be valid during this period. The influence of individual variables on intrarater reliability was examined, and it was found that higher age and lower educational levels influenced reliability negatively.

Even if the evaluation and interpretation of the OCDS score were not the actual purpose of the study, it is of interest to note that the mean values of the obsessive and compulsive subscale scores was well as of the total scale score were considerably lower in this study than in that performed by Anton et al. [1], although the standard deviations were very similar. Interestingly, the results obtained in the Dutch study [4] were also in the same range, suggesting that this discrepancy could depend on different levels of severity due to differences in the health care systems; alcoholic patients could possibly have more easy access to hospitalization in Belgium and in the Netherlands than in the USA.

In conclusion, this study confirms the excellent general psychometric properties of the OCDS and shows that this translated French version can be used under conditions in which it is of interest to measure the cognitive aspects of craving. 


\section{Appendix}

\section{FRENCH TRANSLATION OF THE OCDS}

Instructions : Les questions suivantes concernent votre consommation d'alcool et votre désir de contrôler cette consommation dans les 7 derniers jours. Veuillez entourer le chiffre en face de la réponse qui s'applique le mieux à votre état.

Q1 Lorsque vous ne buvez pas d'alcool, combien de votre temps est occupé par des idées, pensées, impulsions ou images liées à la consommation d'alcool ?

0 A aucun moment

1 Moins d'une heure par jour

2 De 1 à 3 heures par jour

3 De 4 à 8 heures par jour

$4 \quad$ Plus de 8 heures par jour

Q2 A quelle fréquence ces pensées surviennent-elles?

0 Jamais

1 Pas plus de 8 fois par jour

2 Plus de 8 fois par jour, mais pendant la plus grande partie de la journée je n'y pense pas

3 Plus de 8 fois par jour et pendant la plus grande partie de la journée

4 Ces pensées sont trop nombreuses pour être comptées et il ne se passe que rarement une heure sans que plusieurs de ces idées ne surviennent

Q3 A quel point ces idées, pensées, impulsions ou images liées à la consommation d'alcool interfèrent-elles avec votre activité sociale ou professionnelle (ou votre fonction) ? Y a-t-il quelque chose que vous ne faites pas ou ne pouvez pas faire à cause d'elles ? (Si vous ne travaillez pas actuellement, à quel point vos capacités seraient-elles atteintes si vous travailliez ?)

0 Les pensées relatives à la consommation d'alcool n'interfèrent jamais. Je peux fonctionner normalement

1 Les pensées relatives à la consommation d'alcool interfèrent légèrement avec mes activités sociales ou professionnelles, mais mes performances globales n'en sont pas affectées

2 Les pensées relatives à la consommation d'alcool interfèrent réellement avec mes activités sociales ou professionnelles, mais je peux encore m'en arranger

3 Les pensées relatives à la consommation d'alcool affectent de façon importante mes activités sociales ou professionnelles

4 Les pensées relatives à la consommation d'alcool bloquent mes activités sociales ou professionnelles 
Q4 Quelle est l'importance de la détresse ou de la perturbation que ces idées, pensées, impulsions ou images liées à la consommation d'alcool génèrent lorsque vous ne buvez pas?

\section{$0 \quad$ Aucune}

1 Légère, peu fréquente et pas trop dérangeante

2 Modérée, fréquente et dérangeante mais encore gérable

3 Sévère, très fréquente et très dérangeante

4 Extrême, presque constante et bloquant les capacités

Q5 Lorsque vous ne buvez pas, à quel point faites-vous des efforts pour résister à ces pensées ou essayer de les repousser ou de les détourner de votre attention quand elles entrent dans votre esprit ? (Evaluez vos efforts faits pour résister à ces pensées, et non votre succès ou votre échec à les contrôler réellement)

0 Mes pensées sont si minimes que je n'ai pas besoin de faire d'effort pour y résister. Si j'ai de telles pensées, je fais toujours l'effort d'y résister

1 J'essaie d'y résister la plupart du temps

2 Je fais quelques efforts pour y résister

3 Je me laisse aller à toutes ces pensées sans essayer de les contrôler, mais je le fais avec quelque hésitation

$4 \quad$ Je me laisse aller complètement et volontairement à toutes ces pensées

Q6 Lorsque vous ne buvez pas, à quel point arrivez-vous à arrêter ces pensées ou à vous en détourner?

$0 \quad$ Je réussis complètement à arrêter ou à me détourner de telles pensées

1 Je suis d'habitude capable d'arrêter ces pensées ou de me détourner d'elles avec quelques efforts et de la concentration

2 Je suis parfois capable d'arrêter de telles pensées ou de m'en détourner

3 Je n'arrive que rarement à arrêter de telles pensées et ne peux m'en détourner qu'avec difficulté

4 Je n'arrive que rarement à me détourner de telles pensées même momentanément

Q7 Combien de verres de boissons alcooliques buvez-vous par jour?

0 Aucun

1 Moins d'un verre par jour

2 De 1 à 2 verres par jour

3 De 3 à 7 verres par jour

48 verres ou plus par jour

Q8 Combien de jours par semaine buvez-vous de l'alcool?

0 Aucun

1 Pas plus d'un jour par semaine 
De 2 à 3 jours par semaine

De 4 à 5 jours par semaine

$4 \quad$ De 6 à 7 jours par semaine

Q9 A quel point votre consommation d'alcool interfère-t-elle avec votre activité professionnelle?

Existe-t-il des choses que vous ne faites pas ou ne pouvez pas faire à cause de cette consommation?

(Si vous ne travaillez pas actuellement, à quel point vos capacités professionnelles seraient-elles affectées si vous travailliez?)

0 Le fait de boire n'interfère jamais - je peux fonctionner normalement

1 Le fait de boire interfère légèrement avec mon activité professionnelle mais l'ensemble de mes capacités n'en est pas affecté

2 Le fait de boire interfère de manière certaine avec mon activité professionnelle, mais je peux m'en arranger

3 Le fait de boire affecte de façon importante mon activité professionnelle

$4 \quad$ Les problèmes d'alcool bloquent mes capacités de travail

Q10 A quel point votre consommation d'alcool interfère-t-elle avec votreactivitésociale?

Existe-t-il des choses que vous ne faites pas ou ne pouvez pas faire à cause de cette consommation?

0 Le fait de boire n'interfère jamais - je peux fonctionner normalement

1 Le fait de boire interfère légèrement avec mes activités sociales, mais l'ensemble de mes capacités n'est pas affecté

2 Le fait de boire interfère de manière certaine avec mes activités sociales, mais je peux encore m'en arranger

3 Le fait de boire affecte de façon importante mes activités sociales

4 Les problèmes d'alcool bloquent mes activités sociales

Q11 Si l'on vous empêchait de boire de l'alcool quand vous désirez prendre un verre, à quel point seriez-vous anxieux ou énervé ?

$0 \quad$ Je n'éprouverais ni anxiété ni irritation

1 Je ne deviendrais que légèrement anxieux ou irrité

2 L'anxiété ou l'irritation augmenterait mais resterait contrôlable

3 J'éprouverais une augmentation d'anxiété ou d'irritation très importante et dérangeante

4 J'éprouverais une anxiété ou une irritation très invalidante

Q12 A quel point faites-vous des efforts pour résister à la consommation de boissons alcooliques? (Evaluez uniquement vos efforts pour y résister et non votre succès ou votre échec à réellement contrôler cette consommation)

0 Ma consommation est si minime que je n'ai pas besoin d'y résister - si je bois, je fais l'effort de toujours y résister 
1 J'essaie d'y résister la plupart du temps

2 Je fais quelques efforts pour y résister

3 Je me laisse aller presque à chaque fois sans essayer de contrôler ma consommation d'alcool, mais je le fais avec un peu d'hésitation

4 Je me laisse aller complètement et volontairement à la boisson

Q13 A quel point vous sentez-vous pousséà consommer des boissons alcooliques?

$0 \quad$ Je ne me sens pas poussé de tout

1 Je me sens faiblement poussé à boire

2 Je me sens fortement poussé à boire

3 Je me sens très fortement poussé à boire

$4 \quad$ Le désir de boire est entièrement involontaire et me dépasse

Q14 Quel contrôle avez-vous sur votre consommation d'alcool?

$0 \quad$ J'ai un contrôle total

1 Je suis habituellement capable d'exercer un contrôle volontaire sur elle

2 Je ne peux la contrôler qu'avec difficulté

3 Je dois boire et je ne peux attendre de boire qu'avec difficulté

4 Je suis rarement capable d'attendre de boire même momentanément 


\section{References}

1. Anton RF, Moak DH, Latham PK: The Obsessive Compulsive Drinking Scale: A self-rated instrument for the quantification of thoughts about alcohol and drinking behavior. Alcohol Clin Exp Res 1995;19:92-99.

2. Anton RF, Moak DH, Latham PK: The Obsessive Compulsive Drinking Scale: A new method of assessing outcome in alcoholism treatment studies. Arch Gen Psychiatry 1996;53: 225-231.

3. Modell JG, Glaser FB, Mountz JM, Schmaltz S, Cyr L: Obsessive and compulsive characteristics of alcohol abuse and dependence: Quantification by a newly developped questionnaire. Alcohol Clin Exp Res 1992;16:266-271.

4. Schippers GM, De Jong CAJ, Lehert Ph, Potgieter A, Deckers F, Casselmann J, Geerlings PJ: The Obsessive Compulsive Drinking Scale: Translation into Dutch and possible modifications. Eur Addict Res 1997;3:116-122.

5. Hunt SM, Alonso J, Bucquet D, Niero M, Wiklund I, McKenna S: Cross-cultural adaptation of health measures. Health Policy 1991;19:33- 44.

6. American Psychiatric Association: Diagnostic and Statistical Manual of Mental Disorders, ed 4. Washington, American Psychiatric Press, 1994.

7. Edwards G: Problems and dependence: The history of two dimensions; in Lader MM, Edwards G, Drummond DC (eds): The Nature of Alcohol and Drug-Related Problems. Oxford, Oxford Medical Publications, 1992, pp 1-13. 